\title{
1. Applying doctoral studies and research on entrepreneurship to teachers' work at HAAGA-HELIA University of Applied Sciences Tarja Römer-Paakkanen
}

\section{INTRODUCTION}

Entrepreneurship is today seen as a key competence for all and is linked to an individual's ability to turn ideas into action. Such skills and attitudes are directly linked to concepts such as creativity, sense of initiative, innovation, pro-activity, determination, independence, responsibility, risk acceptance and the ability to plan and manage projects. To promote those skills it is necessary to introduce cross-disciplinary approaches to entrepreneurship education, to integrate entrepreneurial support activities for guidance professionals and teachers/lecturers, and to embed interactive teaching. These changes will all require new models of working and new policy frameworks. Consequently, there is wide recognition of the need for effective training, guidance and support methods for teachers and guidance professionals. It is essential that those involved in career guidance and entrepreneurship education are fully trained, supported and have access to guidance materials to improve training. In line with the increased emphasis on the importance of practical entrepreneurial skills of young people, there is a need to equip teachers with the necessary competences to deliver this type of practical learning. Higher education institutions (HEIs) in Europe have a particularly important role in supporting students in their efforts to establish and run potential high-growth companies that are built around innovation and scientific research. Ensuring that the staff of HEIs' careers services have expertise in entrepreneurship is one way of making sure that prospective and current students are informed about available enterprise support and related learning opportunities (CEDEFOP 2011, 54, 93-6, 158).

According to the Finnish Ministry of Education, the aims set for 
entrepreneurship education and training relate to the following points: (a) the creation of a culture of entrepreneurship and nurturing a climate friendly to entrepreneurship; (b) the promotion of internal and external entrepreneurship, the creation of new business, and innovation; and (c) the support of entrepreneurs and their businesses and generating changes in businesses. The first and second of these aims apply to all pupils and students in the education system (Ministry of Education 2004).

The Ministry of Education has taken teachers' entrepreneurship education and training as one of the priorities. The aim in adult education and training is to ensure that teachers have the required competencies and to develop further specialist qualifications and other continuing vocational training to meet entrepreneurs' needs. Moreover, the goal is to undertake other adult education projects relating to entrepreneurship, to assist adult education and training centres' tasks in entrepreneurship, and to promote regional co-operation between different partners. The aim of universities of applied sciences (UAS) is to:

- support teachers' in-service training,

- disseminate experiences and results gained from piloting the postgraduate university of applied sciences degrees in the degree programme in entrepreneurship,

- implement the proposals put forward by the committee on the development of business know-how in higher education, and

- promote business incubator activities.

In terms of research the aim is to promote the utilization of research findings, to highlight students' co-operation in writing theses and completing postgraduate projects, and to develop teacher training (Ministry of Education 2004).

The target of entrepreneurship education is to learn to understand entrepreneurship, to learn to be entrepreneurial and to learn how to become an entrepreneur (Hytti 2002, 16). Moreover, entrepreneurial learning can be one target of entrepreneurship education (Rae and Carswell 2000). According to Isokangas $(2009,95)$, if the target is that people learn and absorb entrepreneurial processes, the pedagogical processes should answer the following challenges:

- The learning methods should have the same kind of ontological and epistemic basis as the entrepreneurial process.

- The learning methods should be holistic, challenging, long-lasting, functional and collaborative. They should create new activities, connect to the ever-changing reality that exists outside the school 
by networking, studying business and how to create new businesses, and connecting different kinds of knowledge to project working in student teams and in learning networks.

- The learning methods should not only emphasize learning in the classroom but also learning outside the classroom; the methods should be student-centred and stress the active and self-organizing role of the students.

- The learning methods should also combine different disciplines and theories, evaluate decisions critically, and include problem and crisis solving and working under stress.

- The teacher's role is to support learning, challenge and encourage students and to be an expert (Isokangas 2009, 95).

To answer the above-mentioned challenges the University of Jyväskylä and HAAGA-HELIA University of Applied Sciences have created a doctoral study programme in entrepreneurship. ${ }^{1}$ The University of Jyväskylä organizes the courses, the seminars and the supervision in Helsinki. The optional supervision is provided by 'a research training group' that consists of the supervisor professors and adjunct professors. The teachers that take part in the project can examine and deepen their knowledge of entrepreneurship in their doctoral dissertations. The aim is that the knowledge and research results can be implemented into the teaching and training work 'at once'. Furthermore, the research problems emerge out of practice, as a result of the needs of UAS, cooperating firms or organizations, the teachers and the students. The doctoral students want to promote entrepreneurship in their UAS, but HAAGA-HELIA also wants to strengthen its image as a high quality educational organization.

\subsection{Targets of the Doctoral Programme}

A group of 41 teachers and other personnel at the Haaga Polytechnic (now the HAAGA-HELIA University of Applied Sciences), the Helsinki Business College and the Business College Helsinki-Malmi started their doctoral studies in Entrepreneurship at the University of Jyväskylä at the end of 2004. Four years later in 2008 a new group of teachers joined the programme. Altogether, between 2004 and 2013 there have been 60 doctoral students in this project, of which about 35 are still active.

By training and educating the personnel and teachers we get a dynamic group of supervisors and mentors for our students. The process allows us to integrate the research into entrepreneurship education and career counselling. The entrepreneurship education and career counselling develop the university students' ability to plan and design their lives. As a result, 
they have the courage and the abilities to affect their own lives and the surrounding society and also to better find their place in society - as employees or entrepreneurs.

In general the doctoral studies aim to provide the doctoral students with some cognitive competencies and some special competences that are needed in academic working life (Ministry of Education 2006a, 30). These competencies are listed in Table 1.1.

The academic objective in the doctoral studies is the following: (a) to get the participants acquainted with their scientific field; (b) to help them focus their research within the chosen field; (c) to develop their critical and independent thinking; (d) to obtain the ability to create new knowledge; and (e) to form a researcher forum where they can change their experiences, develop their skills, share their knowledge and follow the entrepreneurial learning methods. The persons taking part in the doctoral study programme undertake a $\mathrm{PhD}$ in entrepreneurship, management or marketing at the University of Jyväskylä.

Along with the above-mentioned general academic objectives, this project aims to produce change agents, who help the organization and its members to develop entrepreneurial spirits and attitudes. The basic practical targets of the doctoral study programme are:

- To promote entrepreneurial orientation and to 'introduce' entrepreneurship into all teaching and training. The personnel would have a positive attitude towards entrepreneurship and entrepreneurship education.

- To enhance understanding of entrepreneurship and the dynamics of small and medium-sized firms in general. The personnel would also be aware of the importance of entrepreneurship in our society.

- To ensure that all the participating teachers are qualified and inspired to encourage their students to develop their business ideas and start their own businesses. The topics of doctoral theses are connected to the various R\&D projects, the daily teaching or entrepreneurship education projects.

Using the experiences of this doctoral study project we aim to create a concept for doctoral studies that can be implemented in the other UAS in Finland or in other European countries.

Teachers are often left on their own - each performing their own experiments, including various topics in entrepreneurship teaching and finding ways of teaching entrepreneurship. In our doctoral study project, the aim is to offer the teachers a broader conceptualization of entrepreneurship and to give them a set of pedagogical tools to develop their own ways of 


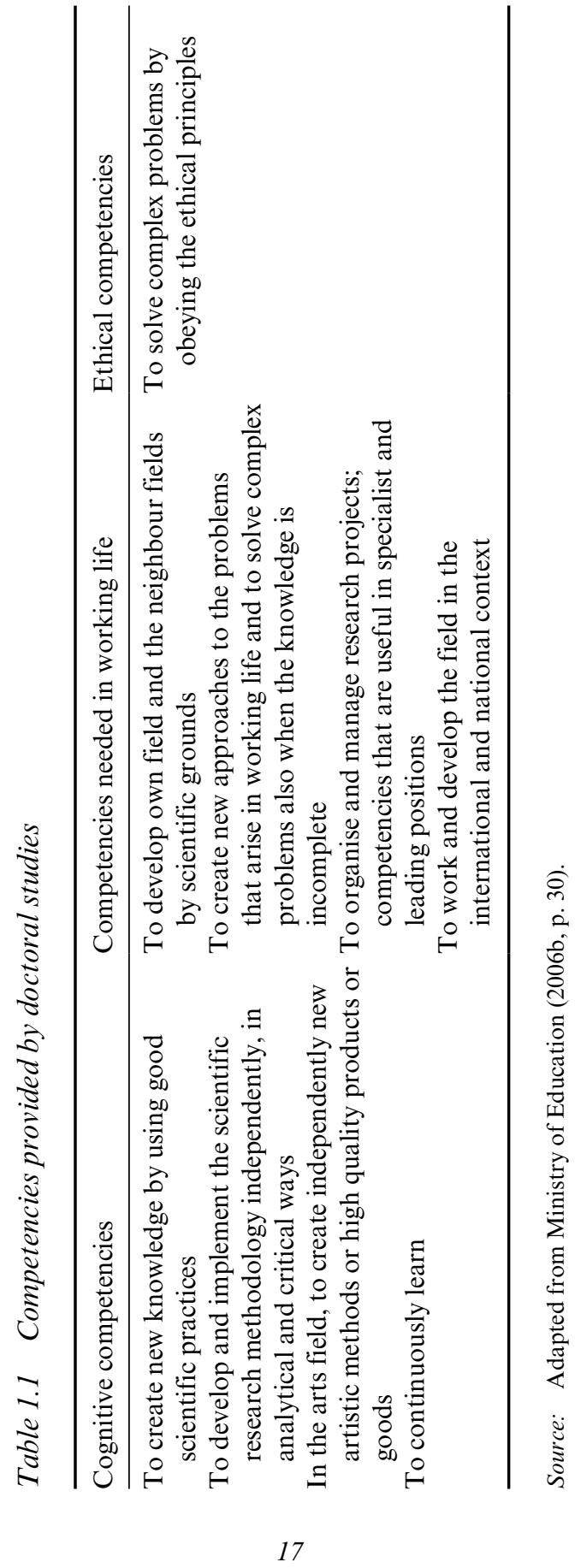


teaching and training the students. It is not possible to encourage people to start their own businesses by only teaching them how to write a business plan and how to manage a firm; a more comprehensive approach is needed.

The teacher education and training model of the HAAGA-HELIA University of Applied Sciences and the University of Jyväskylä is based on current research, positive attitudes towards entrepreneurship and a comprehensive understanding of entrepreneurship. According to Blenker et al. (2004), in entrepreneurship education the focus should not primarily be on external entrepreneurship (i.e. the process of creating and developing individual businesses), but rather on developing people to express enterprising behaviour. This method covers both those who may want to run their own businesses as well as people whose enterprising behaviour may take some other form. In the latter case, other than the actual entrepreneurial creation of a firm, the enterprising behaviour may thus take place in a non-economic context.

The entrepreneurship education process is based on the teacher's and students' pre-understanding of the phenomenon of entrepreneurship. As the process advances the literature, theories and other studies are being implemented into practice and hence at the same time the understanding of entrepreneurship becomes more in-depth. The learning and teaching paradigm implemented here is based on constructivism, which says that people construct their own understanding and knowledge of the world, through experiencing things and reflecting on those experiences. When we encounter something new, we have to reconcile it with our previous ideas and experience, maybe changing what we believe, or maybe discarding the new information as irrelevant. In any case, we are active creators of our own knowledge. To do this, we must ask questions, explore and assess what we know. According to constructivism, knowledge is not a reflection of the world that can be transferred to another environment as such, but it has always first been constructed by the individual or by the social community (Kotila 2003, 14).

Figure 1.1 describes the entrepreneurship education process used here, which has its foundation in the pre-understanding or experiences of the doctoral student in entrepreneurship. As time goes on and literature, theories and studies are adopted and implemented in practice, individuals move towards a deeper understanding of entrepreneurship. In the process, doctoral students are not left alone but they are provided with strong personal and group guidance and supervision. This learning process is based on constructivism as in this process knowledge is not seen as an objective reflection of the world but is always built up or developed by an individual or by a social community (Kupke 2008, 10). Knowledge is not transferred 
Entrepreneurship Education Process
Entrepreneurial orientation (EO) and intrapreneurial orientation (IO) (at both the organisational and personal level):

Creativity, sense of initiative, innovation, pro-activity, determination, independence, responsibility, risk acceptance, and the ability to plan and manage projects

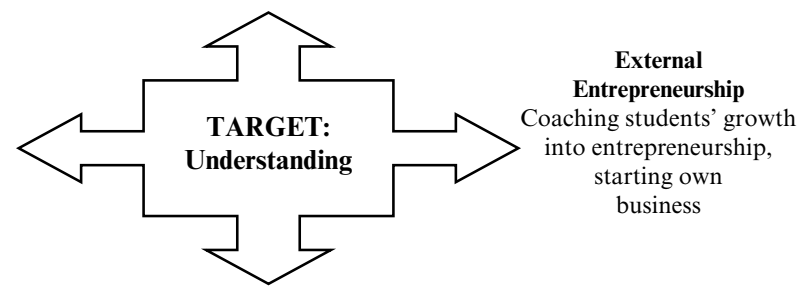

Guiding, coaching and mentoring:

RESULT:

Apply theories in teaching Curriculum

Lectures

Literature

Paradigms

Concepts

Definitions

Models

Methods

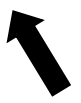

THEORY:

Acquire theoretical understanding
Discussions with supervisors, learning from peers, entrepreneur stories and cases, visitors, excursions

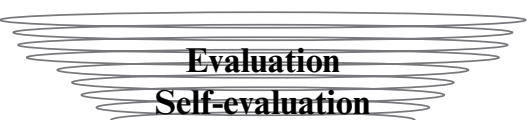

Coaching and Supervision Studies

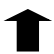

Previous experiences and studies $=$ Pre-understanding
RESULT:

Knowledge for decision making, knowledge for guiding and teaching entrepreneurship, knowledge for developing curriculum

Figure 1.1 From pre-understanding to understanding: exploring, learning, and absorbing entrepreneurship in the doctoral study process

to a learner but he or she constructs it according to his or her own objectives (Ojanen 2000, 19, 40-44).

According to CEDEFOP $(2005,11)$ guidance refers to a range of activities that enables citizens of any age and at any point in their lives (lifelong) to identify their capacities, competences and interests, to make meaningful educational, training and occupational decisions and to manage their individual life paths in learning, work and other settings in which these capacities and competences are learned and/or used (life-wide). Guidance is provided in a range of settings: education, training, employment, community and private (CEDEFOP 2005, 11). In universities the typical way of guiding is through seminars, where the students meet and explore the theses and dissertations of each other under the guidance of their supervisors. Kupke $(2008,28)$ points out that seminars could be made more 
effective by implementing Peavy's sociodynamic model and giving the students some group exercises, as writing a thesis or dissertation is a process that requires continuing learning. According to Kupke, when working in groups, people 'smash in' the old approaches with new knowledge, as in constructivism. This produces learning and empowerment for the members of the group, and they also learn to manage their own situation and the process of writing the thesis or dissertation.

The process in Figure 1.1 results in promoting the internal entrepreneurship, which means that people become more active, innovative and willing to take the initiative in their work and their lives despite the fact that they may not actually start their own businesses. Successful entrepreneurship training also produces people who really want to start businesses. It is to be hoped that within the next decade, more people will choose an entrepreneurial career. Finland needs people who understand entrepreneurship and the dynamics of small and medium-sized firms so that they are skilled and knowledgeable in the decision making that influences the life of entrepreneurs.

The doctoral study process in Figure 1.1 also results in entrepreneurial orientation (EO) on both the individual and the firm level (the University of Applied Sciences in this case). Lumpkin and Dess $(1996,138)$ propose that EO demonstrates how firms could organize themselves to respond to a range of market changes. When one talks about changes in a school or any other educational organization context, it would be better to use the term intrapreneurial orientation (IO), which means that a school is proactive with regards turbulent changes by constructing a strategy to tackle the challenges and implementing it by using an IO construct.

\subsection{Target of this Chapter}

In this project action research methodology is implemented. According to O'Brien (2001) there is a dual commitment in action research to both study a system and concurrently to collaborate with members of the system in changing it in what is together regarded as a desirable direction. The focus in this chapter is on describing the doctoral study project and the experiences of the doctoral students. The theoretic framework evolves as the action research process proceeds.

This first stage empirical study investigates what kind of experiences the doctoral students have had with connecting their doctoral studies and academic research on entrepreneurship to their daily teaching, training and developing work. The research questions are:

- How have doctoral students experienced this doctoral study programme? (Doctoral studies) 
- How have they implemented the studies and research into their work at HAAGA-HELIA University of Applied Sciences? (Practice)

- What are their experiences of the research process and the guidance given in seminars and in personal supervision sessions? (Research)

In the long run the goal is also to explore and evaluate how the doctoral programme has influenced the EO of HAAGA-HELIA, and then we can talk about qualitative evaluation research, action research or co-operative research as the target is to investigate the co-operation of the doctoral students and to evaluate and develop this co-operation (Syrjälä et al. 1996, 16, 57; Saarela-Kinnunen and Eskola 2001, 159). In this project we can also implement developmental work research methods, as this programme aims to develop significant long-term activity (Engeström 2004, 9).

\section{THEORETICAL FRAMEWORK OF THE DOCTORAL PROGRAMME: TRIANGULATION OF DOCTORAL STUDIES, PRACTICE AND RESEARCH}

In this doctoral programme, an expansive learning approach is implemented. Expansive learning means the processes by which a work organization resolves its internal contradictions in order to construct qualitatively new ways of working. According to Engeström (1987 and 2002, 92) expansive learning begins when someone questions the existing practices and starts the developmental cycle as follows: (a) questioning of the existing standard practice; (b) analysing the existing practice (historical analysis and actual empirical analysis); (c) modelling the new solution; (d) forming the new model; (e) implementing the new model; (f) reflection of the process; and ( $\mathrm{g}$ ) consolidating the new practice. According to Eerola (2007, 37), through expansive learning an organization can develop the practices and create a new procedure or policy that can be spread throughout the whole organization.

In this project the new practices are entrepreneurship and entrepreneurial learning, which are aimed to be spread out over the organization to encourage the organizational culture to become more entrepreneurial. Thus expansive learning process can be presented as follows in this project:

1. Questioning of existing standard practice and analysing existing practice ( $a$ and $b$ ): There are many good practices in entrepreneurship education in UAS in Finland but still the EO is not applied in educational organizations and we are missing the entrepreneurial pedagogy. 
2. Modelling the new solution (c): The entrepreneurial oriented UAS is based on entrepreneurship, entrepreneurial learning and pro-activity.

3. Forming new model and implementing the new model ( $\mathrm{d}$ and e): Entrepreneurship education research in the UAS context and implementing the results when developing pedagogy and new curriculum in UAS.

4. Reflection of the process (f): Researching the doctoral programme and the experiences of the doctoral students.

5. Consolidating the new practice $(\mathrm{g})$ : Implementing the results of the doctoral dissertations in the UAS context.

This doctoral project connects theoretical studies and academic research with the participating teachers' practical work. We can talk about the triangulation of doctoral studies (understanding of entrepreneurship theories), research (entrepreneurship research and doctoral dissertations) and practice (implementing theories in teaching and training of entrepreneurship). Figure 1.2 shows the triangulation. The objective is a wide understanding of entrepreneurship and the internal entrepreneurship that creates an entrepreneurially oriented environment for the students.

In addition to doctoral courses, the doctoral students meet once a month at seminars in which they present some problem areas of their research, discuss their topics and become familiar with the scientific way of discussing and writing. In addition to their own research topics the doctoral students discuss the current problem areas of their daily work: development of their UAS, curriculum, pedagogy and the educational system. The doctoral students are encouraged to challenge themselves and others, to ask questions, and to discuss the topics and the methodology so that all seminar participants also learn from their peers. Group dynamics and peer comments are very important. This kind of learning can also be called collaborative learning, which combines individual and social learning where participants construct shared meanings and understanding by producing interactions where diverse viewpoints can be negotiated, co-ordinated and reflected upon to produce performance that no individual can do alone (Dillenbourg 1999, 13; Stahl 2003, 1).

\section{METHODOLOGY}

According to O'Brien (2001), action research (AR) has various names (participatory research, collaborative inquiry, emancipatory research, action 


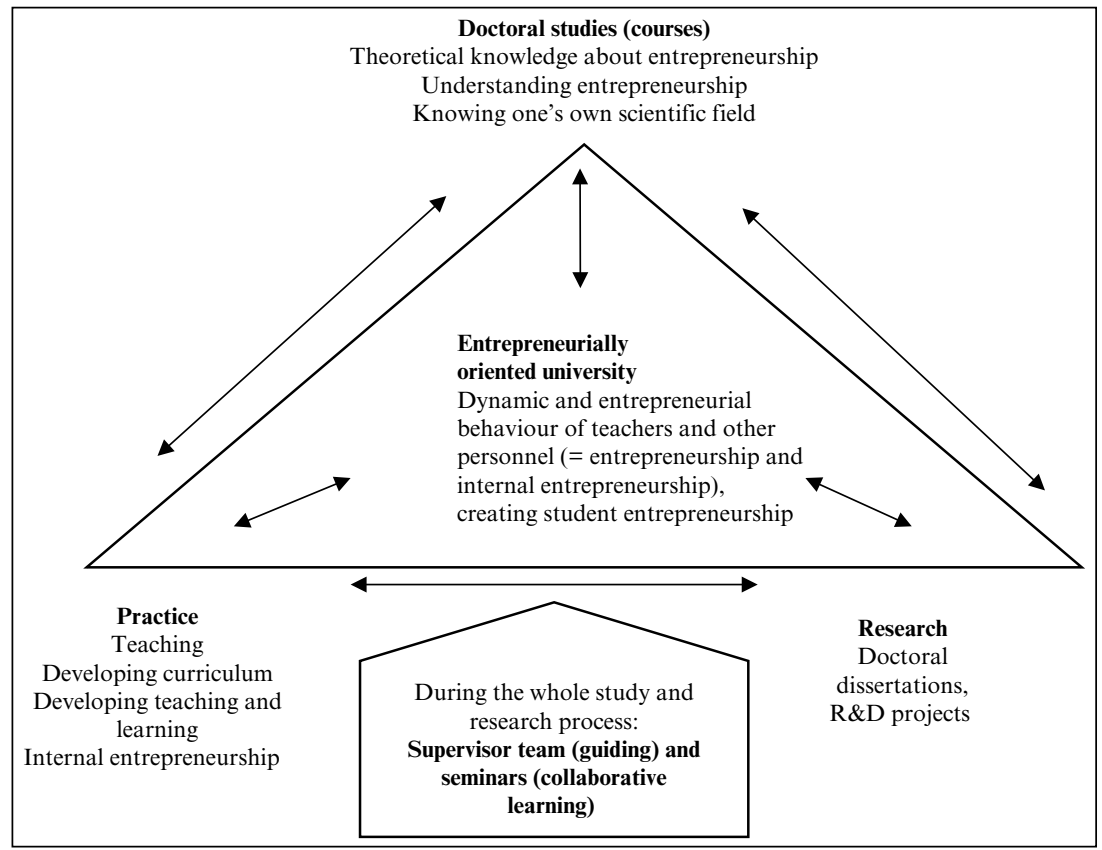

Figure 1.2 Triangulation of doctoral studies, practice and research

learning or contextual action research), but all these are variations of the same theme. Put simply, AR is 'learning by doing' in which a group of people identify a problem (diagnosing), do something to resolve it (action planning and taking action), see how successful their efforts were (evaluating and specifying learning) and if not satisfied, they try again (see Table 1.2). While this is the essence of the approach, there are other key attributes in AR that differentiate it from common problem-solving activities that humans engage themselves in every day. O'Brien's (2001) definition stands:

Action research aims to contribute both to the practical and to further the goals of social science simultaneously. Thus, there is a dual commitment in action research to study a system and concurrently to collaborate with members of the system in changing it in what is together regarded as a desirable direction. Accomplishing this twin goal requires the active collaboration of researcher and client, and thus it stresses the importance of co-learning as a primary aspect of the research process.

As the author of this paper is a member of the supervisor team and a coleader of the project, she is a researcher in the very environment in which 
Table 1.2 Processes of action research implemented in this doctoral study project

$\begin{array}{ll}\text { Diagnosing } & \text { A lack of entrepreneurs in Finland: } \\ & \rightarrow \text { Entrepreneurship education and training at all school levels } \\ & \text { and especially in higher education (HIE) is needed. } \\ \rightarrow & \text { Successful entrepreneurship education and training occurs } \\ & \text { in entrepreneurial oriented organisations. } \\ \rightarrow & \text { More skilled and entrepreneurially oriented teachers are } \\ & \text { needed. }\end{array}$

the research is carried out (cf. Syrjälä et al. 1996, 33). Action researchers typically see themselves as research experts, facilitators and sounding boards for the members in the organization. This requires their active involvement and interaction with the target group (Palmu 1998).

The first follow-up research for the doctoral programme started in June 2011 as the doctoral students were invited to two focus-group interviews (a total of 12 participants) and also some personal discussions were conducted with doctoral students and those who had already completed their doctorate. In those discussions the focus was on examining the experiences of the students and of the whole research and supervision process.

The research data were collected from both focus-group interviews and personal discussions with the doctoral students. In the interviews and discussions, they freely explained their own notions and thoughts, and reflected on their experiences with each other. According to Flick $(1998,115)$ a focus-group interview is an interview with a small group of people on a specific topic. Groups are typically six to eight people who 
participate in the interview for 30 minutes to two hours. Focus groups are useful especially when the research topic is new or when the aim is to find out some new ideas. Hyysalo (2009) reminds us that focus-group interviews have also some risks and limitations: the discussion can be a loose exchange of opinions of the given topics and it easily starts to repeat some common idioms and opinions instead of discussing some concrete and instructive experiences. These risks and limitations did not exist in our focus-group interviews as the participants were very interested in discussing the topics and keen to detail their experiences.

After transcribing and organizing the data, the transcripts (46 pages) were analysed using the framework analysis method. Rabiee (2004) refers to Ritchie and Spencer's (1994) framework analysis, but also incorporates some key stages of the framework analysis as described by Krueger and Casey (2000) when describing the different phases of framework analysis.

According to Ritchie and Spencer (1994) the process of data analysis begins during the data collection by skilfully facilitating the discussion and generating rich data from the interview, complementing it with observational notes and typing up the recorded information. This stage is followed by familiarization with the data, which can be achieved by listening to tapes, reading the transcripts in their entirety several times, and reading the observational notes taken during the interview and the summary notes written immediately after the interview. The aim is to become immersed in the details to get a sense of the interview as a whole before breaking it down into parts. The second stage involves identifying a thematic framework by writing memos in the margin of the text. At this stage descriptive statements are formed and an analysis is carried out on the data under the questioning route. The third stage, indexing, comprises sifting the data, highlighting and sorting out quotes and making comparisons both within and between cases. The fourth stage, charting, involves lifting the quotes from their original context and re-arranging them under the newly developed appropriate thematic content.

Krueger and Casey (2000) suggest that the researcher should read each quote and answer these four questions:

1. Did the participant answer the question that was asked? If yes, go to question 3. If no, go to question 2. If don't know, set it aside and review it later.

2. Does the comment answer a different question in the focus group? If yes, move it to the appropriate question. If no, go to question 3.

3. Does the comment say something of importance about the topic? If yes, put it under the appropriate question. If no, set it aside. 
4. Is it something that had been said earlier? If yes, start grouping like quotes together. If no, start a separate pile.

After arranging the data by thematic content it is ready for the final stage of analysis, i.e. mapping and interpreting. The task is not only to make sense of the individual quotes, but also to be imaginative and analytical enough to see the relationship between the quotes and the links between the data as a whole (Rabiee 2004). Krueger and Casey (2000) suggest the following headings as a framework for interpreting coded data: words; context; internal consistency; frequency and extensiveness of comments; specificity of comments; intensity of comments; and big ideas.

\section{RESULTS}

After almost nine years (2004-13) some quantitative results of the project can be presented: there have been 13 doctoral dissertations, six licentiate theses and more than 20 master's theses completed. By the autumn of 2014 we are expecting at least five more doctoral dissertations to be completed. During this project the doctoral students have written more than 50 conference papers or articles on the field of entrepreneurship.

At HAAGA-HELIA we have approximately 10,500 students and 650 employees. About 60 of our employees have a doctoral degree. In such a large organization 30 additional doctors may seem like a small number of change agents. However, together with their colleagues and team members, and together with those teachers and students who are entrepreneurs or have experience of entrepreneurship, they can affect and develop the EO of the organization.

\section{Table 1.3 Students that have participated to the doctoral study programme}

$\begin{array}{ll}\text { Participated in the classes } & 60\end{array}$

- participated in the classes, seminars and supervision and started $\quad 40$ doctoral dissertation

- participated in the classes and seminars, but are doctoral students 20 at another university

Has completed the doctoral dissertation

Has completed licentiate thesis, working on doctoral dissertation $\quad 5$

Active doctoral students, working on doctoral dissertation 9

Has left the project (has changed employer, etc.) 13 
In order to get some qualitative results from this project the data gathered by focus-group interviews and personal interviews are reflected on with regard to the framework of the project and the research questions.

\subsection{Doctoral Studies}

The doctoral programme for teachers is a concept that not only takes into account the personal skills, requirements and objectives of the students, but which also affects the entire organization. The studies are tailored to the needs of HAAGA-HELIA, and the courses take place on its premises so that it is easier for the doctoral students to participate in them. The University of Jyväskylä arranges similar doctoral courses in entrepreneurship, family business and entrepreneurship education at the Central Ostrobothnia University of Applied Sciences. During the eight-year period, several courses for doctoral students were arranged. Some themes for the courses are listed below:

- academic research process and research plan;

- academic writing;

- entrepreneurship and family business examined using the views and methods of future research;

- in-depth case studies in entrepreneurship and family business: data collection, analysis, interpretation, conclusions and overall quality when using an in-depth case study approach;

- growing up to entrepreneurship;

- internal entrepreneurship and innovativeness;

- research paradigms of entrepreneurship;

- family business and its governance;

- entrepreneurial marketing; and

- networking and inter-firm co-operation.

The doctoral students appreciated that their employer had provided them the possibility to study at their own work place and that their academic enthusiasm had been supported by making the personal supervision easily accessible and attainable:

easy start, easy accessibility - you do not need to travel when you need some advice and supervision or when attending the courses and seminars

without this project it would be easy to drop out. 
Also discussions during the courses are mentioned as important learning situations. The students said that they enjoyed seeing other doctoral students making progress and moving on with their research. They also felt that everyone in the group had something to give to and teach the others and that the supervisors also learned from the discussions:

the whole atmosphere is important ... it is important that you can freely discuss and communicate with the peers and with the supervisors

supportive and constructive critics are important

in guiding it would be useful also to use small groups - some of the problems and questions are common in certain stages of the process

in the seminar you can get peer support.

\subsection{Practice: Developing Teaching and Learning}

An essential prerequisite for entrepreneurship education is that the teachers are skilled and enthusiastic in the field. According to Laakkonen (2003, 281), dynamic UAS continuously develop, learn, create and adapt new environments. Changing the culture in schools means that teachers and other personnel must adapt new schemas and create new meanings and contents in their own work. Along with conscious and rational elements in schools, their organizational culture also consists of subconscious and mental elements (Laakkonen 2003, 281-2).

The final aim of our doctoral study programme is to create a learning environment that is more entrepreneurial, which also helps the bachelor or master students to socialize into entrepreneurship. Management input, clear organizational vision, and pro-learning and research environments are key elements in this entrepreneurship education process. The doctoral project also increases teacher co-operation and discussion over entrepreneurship, as everyone in the school context encounters it in their immediate teams or when participating in various events and explorations that are part of this project. It is fair to talk about extending entrepreneurship.

Teachers must themselves feel that entrepreneurship is important and that it is one possible opportunity for their students. The recourses, attitudes and skills of the teachers are the critical preconditions to entrepreneurship education. Teachers with personal experience of entrepreneurship and positive attitudes towards entrepreneurship and entrepreneurship education are the most convincing coaches and guides for the entrepreneurial students (Ristimäki 2002, 57, 68; Römer-Paakkanen and Pekkala 2008).

Based on studies in the Finnish educational context (Paajanen 2001, 233; 
Römer-Paakkanen and Pekkala, 2008) the students have stated that an entrepreneurship teacher should work like an entrepreneur by being creative, dynamic, risk-taking, initiative oriented, hard-working, responsible, and action motivated. A teacher should also possess a positive attitude towards entrepreneurship, which means appreciating market economy, business life, business, enterprises, entrepreneurs and work. An ideal entrepreneurship teacher must adopt modern learning paradigms. He or she should encourage students into entrepreneurship and use learning methods that activate students, favour student orientation and emphasize social interaction.

Figure 1.3 illustrates how those who participate in the project create a culture of entrepreneurship which extends to the other parts of the schools, making it easier to include entrepreneurship in all teaching activities.

The participating teachers are now wearing the 'entrepreneurial spectacles': they observe their environment and society from the viewpoint of entrepreneurs and small firms. After almost nine years the programme has started the process towards more integrative, wider and more holistic entrepreneurship education programmes and curricula.

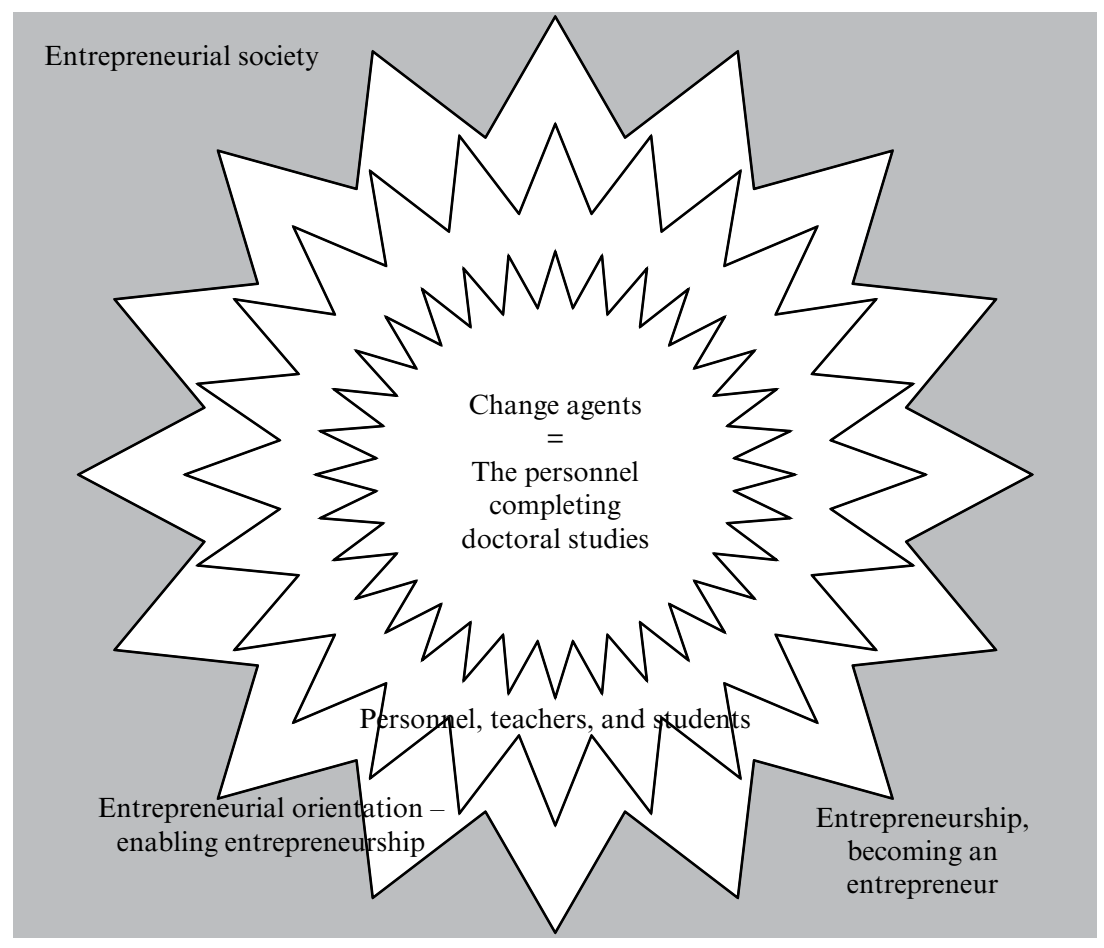

Figure 1.3 Extending entrepreneurship in the higher education context 
The teachers taking part in this programme become change agents who can influence the learning environment of UAS and thereby influence entrepreneurship studies, entrepreneurship pedagogy and the knowledge and attitudes of UAS students. According to Eerola (2007, 38), change agents can start the collective change and influence many systems such as those in schools and in working life. Change agents have an interventional character: he or she is interested in the whole operating system and in the changes in its processes. According to Eerola, UAS and vocational education organizations can become change agents that co-operate with local organizations and working places, and can offer their expertise and know-how to the organizations that are in the middle of change processes.

\subsection{Research: Doctoral Dissertations}

Although the main focus in this doctoral study programme is entrepreneurship and entrepreneurship education, the research topics are very heterogeneous and range from small business entrepreneur competencies to entrepreneurship of elite athletes. The topics of the dissertations that have been completed as of February 2014 include (see Appendix 1A.1 for further details):

- A journey into the core of the occupational competence and attitudes of small business entrepreneurs. A study based on a review of literature and a DACUM analysis (Westerholm 2007).

- Corporate governance, intrapreneurship and effectiveness in the UAS (Nyyssölä 2008).

- Same education - different careers. A study of Finnish nationals who have studied applied linguistics in the University of Mainz, Germany, during 1965-2001, and their working development as employees, freelancers and entrepreneurs (Takanen-Körperich 2008).

- Cultural competence when operating in Southern and Eastern China. An interpretation of some Finnish business managers' experiences in China as an illustration (Rankinen 2008).

- Family businesses as an economic resource. Ownership, scale and profitability of middle-sized and large-sized businesses in Finland in 2000-05 (Tourunen 2009).

- Mastery as capital - how growth into the elite athlete and mastery capital advances the growth into entrepreneurship (Pekkala 2011).

- Teaching professionals and masters of mosaic - work cultures as the context of action of the teachers in UAS (Mäki 2012). 
- Why did electronic B2B marketplaces fail? Case study of an agricultural commodity exchange (Luomakoski 2012).

- Constructing an opportunity centred collaborative learning model through and for entrepreneurship (Suonpää 2013).

- The experiences of and differences between teachers in developing accreditation of prior experimental learning from the perspective of intrapreneurship, psychological ownership and joy of work (Niemelä 2013).

- Intrapreneurship as number one: multiple-case study of intrapreneurship and adult student graduation (Salo 2013).

- Ideological tensions during the succession process (Rauhala 2013).

- Russian immigrant entrepreneurship in Finland: narratives of eight Russian immigrant entrepreneurs (Sandelin 2014).

As entrepreneurship as a research field is quite wide, the doctoral students needed quite a lot of personal supervision before they found their own way of approaching entrepreneurship research and their own focus and research problem. The informants were extremely satisfied with the possibility of receiving a lot of personal guidance and supervision during their study and research process. According to the interviewed doctoral students, the atmosphere during supervision sessions and seminars is very important for their motivation and strength to continue with their studies and research:

the atmosphere in the supervision sessions is very important! - it is important that the supervisor is not judging but making a constructive conversation

the supervisors are really eager and devoted - they are positive, they really are positively supporting you

you can always ask everything, the supervisors never give staggering answers

in the beginning (of the research) they let a thousand flowers bloom.

The doctoral students said that it is important that after every supervision session they can feel that they have moved on with their own thinking. They are happy even if they only get one piece of advice or tip for a reference to help them continue along their path of thinking:

the supervisor can find the essential from my thinking in writing - after that I can myself catch the rest of my idea

I have the feeling that I always get something in the supervision sessions regular meetings - milestones - small steps 
it is good that it is not essential to have enormous achievements or outputs when meeting the supervisor - you are allowed to discuss small questions and even to discuss without any text.

In the discussions the doctoral students were a little bit critical towards themselves and towards their activity in the supervision sessions:

it is important to write down one's ideas and to give the supervisors something to read - and to give the supervisors also time to read the texts beforehand ....

As the studies made progress the interviewees felt that they were members of the academy and meetings with supervisors were more akin to discussions between two equal researchers. In the later stage of the dissertation process the doctoral students become real specialists in their topics, hence the supervisors do not have so much to offer anymore:

at some stage you start to feel that you also can give something to your supervisor - the supervisor starts to learn from you ...

The interviewees explained that, on the one hand, the supervisors should know how to support the doctoral students but, on the other, they hope that the supervisors can draw the lines if the novice researcher is too eager to adopt new ideas over and over again. They said that the supervisor must have the ability to recognize particular stages of the research process and give the researcher the kinds of challenges that the novice researcher can face:

you need encouragement and good questions - like: How are you planning to continue from here? What do you mean by that? and so on.

sometimes you have some good ideas in your head, but you have not recognized them - and a good supervisor can realize what you are meaning or aiming to say - a good way is that the supervisor knows or feels what you need ...

the supervision changes during the process - a good supervisor can educate you and bring up your thinking - the supervisor notices when you are developing and going ahead...

everyone has a personal way of learning and doing ... the supervisor should take account that some people need more time or that someone needs more discussion

everyone can proceed in his or her own rhythm

people in different stages of research are encouraged in different ways ... 


\section{CONCLUSIONS}

As a conclusion from the interviews it can be said that all the participating doctoral students are very satisfied with the programme as a whole: with the studies, with the supervision and guidance, and with the knowledge, skills and competencies they have gathered during the programme and during the process. The concept of the programme is functioning well and fits the students' needs and challenges with regard to combining their teaching work and private life with the challenges of doctoral studies and research work. Also, HAAGA-HELIA as the employer has been satisfied with the programme's mix of academic research and R\&D along with the development of teaching and pedagogy in the university.

After almost nine years of the teachers' doctoral project, it is fair to say that entrepreneurship has become more visible at HAAGA-HELIA: The participating teachers are wearing the 'entrepreneurial spectacles'; they observe their environment and society from the viewpoint of entrepreneurs and small firms. Encouraging entrepreneurship through education is possible when we create genuine opportunities and resources for teachers to learn about the field, to deepen their knowledge and understanding of it and also to allow them to adopt creative and entrepreneurial working methods. After completing the project at the end of 2013, we can evaluate the entire project and its influence on the general EO in our UAS. At this stage, we already know that the doctoral studies have started the process towards more integrative, wider and more holistic entrepreneurship education programmes and curricula, and that the teachers are transferring their understanding and theoretic knowledge to their teaching.

According to Ristimäki $(2002,46)$, developing entrepreneurship education has four levels: (a) business subjects are changed to entrepreneurship; (b) there is some theoretic knowledge about entrepreneurship; (c) teaching methods support the change of behaviour and action; and (d) the school socializes people to entrepreneurship. Our experiences in this project show how the entrepreneurship education process in the higher education environment is not as linear as the four levels Ristimäki suggests. Rather, it is more a search and learn loop, like a spiral process in which the levels become more inter-dependent and co-existing. The results of the process so far could be summarized as follows:

1. The fact that we have started this doctoral programme is an illustration of entrepreneurial attitude and innovative ways of working.

2. Our process has been independent, proactive and innovative, and we have used personnel education in order to aim for a process of change in which an organization becomes more entrepreneurially oriented. 
3. This process has resulted in changes in the curriculum so that entrepreneurship courses form larger topic areas that cover the starting and developing phases of small and medium-sized businesses and personal growth towards entrepreneurship (modules within professional studies).

4. We are well under way in applying the teachers' theoretical knowledge and deepening the understanding of entrepreneurship in degree planning and in actual teaching. The teachers now perceive the surrounding world through 'entrepreneurial spectacles', observing it from the point of view of entrepreneurs and small and medium-sized businesses.

5. As the teachers are learning about entrepreneurship and intrapreneurship they might also adopt more dynamic and proactive ways of working.

6. The school offers pre-incubation and start-up services. Also an entrepreneurship path that helps to combine studies with working in one's own or the family business is offered.

As the results of this project are being implemented in all courses, and more entrepreneurship courses, experiences and opportunities are being offered to students, entrepreneurship will become more visible at HAAGA-HELIA. In that kind of entrepreneurial environment, students' willingness to become entrepreneurs is likely to increase. According to Nevanperä (2003), a long and effective entrepreneurship education has a positive effect on students' entrepreneurial attitudes.

The long-term social objective of our doctoral programme is to encourage more people to adopt entrepreneurship. The project increases teachers' knowledge and understanding of entrepreneurship, its risks and opportunities. When teachers possess a comprehensive understanding of the topic, they are able to encourage students to adopt the field, and this in turn will take Finland closer to being an entrepreneurial society.

\section{NOTE}

1. In Finland the UAS (i.e. polytechnics) mostly conduct R\&D geared towards the needs of business and industry, and are usually linked to the structure and development of the regional economy. The universities are responsible for scientific research and researchbased higher education, including postgraduate education. Doctoral degrees are only awarded by universities (Ministry of Education 2006b, 42). 


\section{REFERENCES}

Blenker, P., Dreisler, P., Faergemann, H.M. and Kjeldsen, J. (2004). 'Entrepreneurship education and university context', in L. Iandoli and M. Raffa (eds), IntEnt2004. Internationalizing Entrepreneurship Education and Training Conference Proceedings. Book of Extended Abstracts and CD-Rom Papers, pp. 81-4.

CEDEFOP (European Centre for the Development of Vocational Training) (2005). 'Improving lifelong guidance policies and systems. Using common European reference tools'. Luxembourg: Office for Official Publications of the European Communities. Available at http://www.cedefop.europa.eu/EN/ Files/4045_en.pdf (accessed 20 February 2014).

CEDEFOP (European Centre for the Development of Vocational Training) (2011). 'Guidance supporting Europe's aspiring entrepreneurs. Policy and practice to harness future potential'. Research Paper No 14. Luxembourg: Publications Office of the European Union. Available at http://www.cedefop. europa.eu/EN/Files/5514_en.pdf (accessed 20 February 2014).

Dillenbourg, P. (1999). 'What do you mean by collaborative learning?', in P. Dillenbourg (ed.), Collaborative Learning: Cognitive and Computational Approaches. Oxford: Elsevier. Available at http://halshs.archives-ouvertes.fr/ docs/00/19/02/40/PDF/Dillenbourg-Pierre-1999.pdf (accessed 20 February 2014).

Eerola, T. (2007). 'Opettajien työelämäjaksot ammatillisen peruskoulutuksen työelämäyhteistyön muotona. Ammatillisesti suuntautuva kasvatustieteen lisensiaatin tutkinto'. School of Education, University of Tampere.

Engeström, Y. (1987). Learning by Expanding: An Activity-theoretical Approach to Developmental Research. Helsinki: Orienta-Konsultit.

Engeström, Y. (2002). Kehittävä työntutkimus. Perusteita, tuloksia ja haasteita. Helsinki: Edita Prima Oy.

Engeström, Y. (2004). Ekspansiivinen oppiminen ja yhteiskehittely työssä. Tampere: Vastapaino.

Flick, U. (1998). An Introduction to Qualitative Research: Theory, Methods and Applications. London: Sage.

Hytti, U. (2002). 'State-of-art of entrepreneurship education in Europe - results from the ENTREDU Project'. Small Business Institute, Turku School of Economics and Business Administration.

Hyysalo, S. (2009). 'Käyttäjä tuotekehityksessä. Tieto, tutkimus, menetelmät. Taideteollisen korkeakoulun julkaisu B 97'. Available at https://www.taik.fi/kirjakauppa/images/bfee4ec00950ec8aaf7f96538f668055.pdf (accessed 20 February 2014).

Isokangas, J. (2009). 'Partneriperustainen harjoitusyritys. Opiskelijat luomassa uutta toimintakokonaisuutta yrittäjyyskoulutuksessa'. Oulun yliopisto. Taloustieteiden tiedekunta, Johtamisen ja yrittäjyyden laitos. Available at http://herkules.oulu.fi/isbn9789514260681/isbn9789514260681.pdf (accessed 20 February 2014).

Kotila, H. (2003). 'Oppimiskäsitykset ammattikorkeakoulutuksessa', in H. Kotila (ed.), Ammattikorkeakoulupedagogiikka. Helsinki: Edita, pp. 13-23.

Krueger, R.A. and Casey, M.A. (2000). Focus Groups: A Practical Guide for Applied Research, 3rd edn. Thousand Oaks, CA: Sage Publications. 
Kupke, R.-K. (2008). 'Opinto-ohjaus yliopistossa. Opinnäytetöiden ohjaus'. Jyväskylän yliopisto. Kasvatustieteiden tiedekunta. Opettajankoulutuslaitos. Ohjausalan Koulutus- ja tutkimusyksikkö. Available at http://urn.fi/ URN:NBN:fi:jyu-2009471371 (accessed 20 February 2014).

Laakkonen, R. (2003). 'Muuttuva opettajuus', in H. Kotila (ed.), Ammattikorkeakoulupedagogiikka. Helsinki: Edita, pp. 273-95.

Lumpkin, G.T. and Dess, G.G. (1996). 'Clarifying the entrepreneurial orientation construct and linking it to performance', Academy of Management Review, 21(1), 135-72.

Ministry of Education (2004). 'Yrittäjyyskasvatuksen linjaukset ja toimenpideohjelma'. Opetusministeriön julkaisuja 2004:18. Koulutus- ja tiedepolitiikan osasto, pp. 14-17. Available at http://www.minedu.fi/OPM/Julkaisut/2004/yrittajyyskasvatuksen_linjaukset_ja_toimenpideohjelma (accessed 20 February 2014).

Ministry of Education (2006a). 'Tohtorikoulutuksen kehittäminen'. Opetusministeriön työryhmämuistioita ja selvityksiä 2006:3. Opetusministeriö. Koulutus- ja tiedepolitiikan osasto. Helsinki. Available at http://www.minedu.fi/ OPM/Julkaisut/2006/tohtorikoulutuksen_kehittaminen (accessed 20 February 2014).

Ministry of Education (2006b). 'Education and science in Finland'. Ministry of Education publications 2006:15. Available at http://www.minedu.fi/export/ sites/default/OPM/Julkaisut/2006/liitteet/eng_opm15.pdf?lang=fi (accessed 20 February 2014).

Nevanperä, E. (2003). 'Yrittäjyys Suupohjan opiskelijanuorten ajattelussa. Tutkimus Suupohjan seudun nuorisoasteen opiskelijoiden yrittäjyysnäkemyksistä sekä yrittäjyysopetuksen opetussuunnitelman kehittämispyrkimyksistä'. Jyväskylän yliopisto. Jyväskylä Studies in Business and Economics, 24. Available at http://urn.fi/URN:ISBN:978-951-39-5161-0 (accessed 20 February 2014).

O'Brien, R. (2001). 'Um exame da abordagem metodológica da pesquisa ação' ('An overview of the methodological approach of action research'), in R. Richardson (ed.), Teoria e Prática da Pesquisa Ação (Theory and Practice of Action Research), João Pessoa, Brazil: Universidade Federal da Paraíba. (English version). Available at http://www.web.ca/ robrien/papers/arfinal.html (accessed 20 February 2014).

Ojanen, S. (2000). Ohjauksesta oivallukseen - Ohjausteorian kehittelyä. Helsingin yliopiston Tutkimus- ja koulutuskeskus. Oppimateriaaleja 99. Saarijärvi: Palmenia.

Paajanen, P. (2001). 'Yrittäjyyskasvattaja. Ammattikorkeakoulun hallinnon ja kaupan alan opettajien näkemykset itsestään ja työstään yrittäjyyskasvattajana'. Jyväskylä Studies in Business and Economics, 16, 231-9.

Palmu, M. (1998). 'Action research in Finland', in I. Hughes (ed.), Action Research Electronic Reader (online), The University of Sydney. Available at http://www. ar.blend-xl.eu/docs/Action\%20research\%20electronic\%20reader.htm (accessed 15 June 2011).

Rabiee, F. (2004). 'Focus-group interview and data analysis', Proceedings of the Nutrition Society, 63, 655-60. doi:10.1079/PNS2004399. Available at http:// journals.cambridge.org/abstract_S0029665104000874 (accessed 20 February 2014).

Rae, D. and Carswell, M. (2000). 'Using a life-story approach in researching entrepreneurial learning: the development of a conceptual model and its implications in the design of learning experiences', Education and Training, 42(4), 220-27. 
Ristimäki, K. (2002). Yrittäjyyskasvatus. Yrittäjyyttä ja kasvatusta. Helsinki: TAT Taloudellinen tiedotustoimisto.

Ritchie, J. and Spencer, L. (1994). 'Qualitative data analysis for applied policy research', in A. Bryman and R.G. Burgess (eds), Analysing Qualitative Data. London: Routledge, pp. 173-94.

Römer-Paakkanen, T. and Pekkala, A. (2008). 'Generating entrepreneurship and new learning environments from students' free-time activities and hobbies', The Finnish Journal of Business Economics. Arenas of Entrepreneurship Education, 3/08. Vammala: Vammalan Kirjapaino Oy, pp. 341-61. Available at http://1ta. hse.fi/2008/3/lta_2008_03_a5.pdf (accessed 20 February 2014).

Saarela-Kinnunen, M. and Eskola, J. (2001). 'Tapaus ja tutkimus = tapaustutkimus', in J. Aaltola and R. Valli (eds), Ikkunoita tutkimusmetodeihin I. Metodien valinta ja aineiston keruu: Virikkeitä aloittelevalle tutkijalle. Jyväskylä: PSkustannus., pp. 158-69.

Stahl, G. (2003). 'Meaning and interpretation in collaboration'. Available at http://www.gerrystahl.net/cscl/papers/ch20.pdf (accessed 20 February 2014).

Syrjälä, L., Ahonen, S., Syrjäläinen, E. and Saari, S. (1996). Ladullisen tutkimuksen työtapoja. Helsinki: Kirjayhtymä. 


\section{APPENDIX 1A.1}

\section{Completed Doctoral Dissertations, February 2014}

Westerholm, Hely (2007), 'A journey into the core of the occupational competence and attitudes of small business entrepreneurs. A study based on a review of literature and a DACUM analysis'. ('Tutkimusmatka pienyrittäjän työvalmiuksien ytimeen. Kirjallisuuteen ja Dacum-analyysiin perustuva kartoitus'), http://urn. fi/URN:ISBN:978-951-39-4030-0 (in English); http://urn.fi/URN:ISBN:978951-39-2841-4 (in Finnish).

Nyyssölä, Hannu (2008), 'Corporate governance, intrapreneurship and effectiveness in the Universities of Applied Sciences'. ('Omistajaohjaus, sisäinen yrittäjyys ja tuloksellisuus ammattikorkeakouluissa'), http://urn.fi/ URN:ISBN:978-951-39-3507-8.

Takanen-Körperich, Pirjo (2008), 'Same education - different careers. A study of Finnish nationals who have studied applied linguistics at the University of Mainz, Germany, during 1965-2001, and their working development as employees, freelancers and entrepreneurs'. ('Sama koulutus - eri urat. Tutkimus Mainzin yliopistossa soveltavaa kielitiedettä vuosina 1965-2001 opiskelleiden suomalaisten urakehityksestä palkkatyöhön, freelancereiksi ja yrittäjiksi'), http://urn.fi/URN:ISBN:978-951-39-3261-9.

Rankinen, Arja (2008), 'Cultural competence when operating in Southern and Eastern China. An interpretation of some Finnish business managers' experiences in China as an illustration'. ('Kulttuurinen osaaminen Etelä- ja Itä-Kiinassa toimittaessa. Illustraationa eräs tulkinta suomalaisjohtajien Kiinakokemuksista'), http://urn.fi/URN:ISBN:978-951-39-3332-6.

Tourunen, Kalevi (2009), 'Family businesses as an economic resource. Ownership, scale and profitability of middle-sized and large-sized businesses in Finland in 2000-2005'. ('Perheyritykset kansantalouden resurssina. Keskisuurten ja suurten yritysten omistajuus, toiminnan laajuus ja kannattavuus Suomessa 2000-2005'), http://urn.fi/URN:ISBN:978-951-39-3470-5.

Pekkala, Auli (2011), 'Mastery as capital - how growth towards becoming an elite athlete and mastery capital advances growth towards becoming an entrepreneur'. ('Mestaruus pääomana - huippu-urheilun tuottama pääoma yrittäjäksi ryhtymisen kannalta'), http://urn.fi/URN:ISBN:978-951-39-4521-3.

Mäki, Kimmo (2012), 'Teaching professionals and masters of mosaic - work cultures as the context of teachers' actions in universities of applied sciences'. ('Opetustyön ammattilaiset ja mosaiikin mestarit: työkulttuurit ammattikorkeakouluopettajan toiminnan kontekstina'), http://urn.fi/ URN:ISBN:978-951-39-4567-1.

Luomakoski, Jari (2012), 'Why did electronic B2B marketplaces fail? Case study of an agricultural commodity exchange', http://urn.fi/ URN:ISBN:978-951-39-4815-3.

Suonpää, Maija (2013), 'Constructing an opportunity centred collaborative learning model through and for entrepreneurship', http://urn.fi/ URN:ISBN:978-951-39-5032-3.

Niemelä, Raija (2013), 'The experiences of and differences between teachers in developing accreditation of prior experimental learning from the perspective of intrapreneurship, psychological ownership and joy of work'. ('Kokemukset ja opettajien väliset erot osaamisen tunnistamisen kehittämisessä. Sisäisen 
yrittäjyyden, psykologisen omistajuuden ja työnilon näkökulma'), http://urn.fi/ URN:ISBN:978-951-39-5044-6.

Salo, Seppo (2013), 'Intrapreneurship as number one - multiple case study of Intrapreneurship and Adult Student Graduation'. ('Yritys hyvä kymmenen Monitapaustutkimus aikuisopiskelijoiden opintojen edistymisestä ja sisäisestä yrittäjyydestä'), http://urn.fi/URN:ISBN:978-951-39-5213-6.

Rauhala, Mariitta (2013), 'Ideological tensions during the succession process'. ('Ideologiset jännitteet sukupolvenvaihdoksen yhteydessä'), http://urn.fi/ URN:ISBN:978-951-39-5438-3.

Sandelin, Reija (2014), 'Russian immigrant entrepreneurship in Finland: narratives of eight Russian immigrant entrepreneurs', http://urn.fi/ URN:ISBN:978-951-39-5595-3. 